\title{
NUTRITIONAL AND HEALTH STATUS OF PRESCHOOL CHILDREN FROM LOCAL WOMEN ENTREPRENEURIAL HOUSEHOLDS IN OHAJI LOCAL GOVERNMENT AREA
}

\author{
IBE, S. N. O \\ Department Of Public Health Technology, School of Health Technology, \\ Federal University of Technology, Owerri.
}

\begin{abstract}
The study aimed at investigating the effect of women entrepreneurship skills on the nutritional and health status of preschool children in three nursery and primary schools in Ohahji Egbema LGA. A total of 197 preschool children aged 2-5 years was selected from three nursery and primary schools in Ohaji Local Government Area. The results showed that preschool children whose mothers were involved in business ventures had higher but significant anthropometric indices than those whose mother were not involved in any business ventures $(p<0.05)$ both in the groups and between sexes. Similar results were obtained between sexes for energy and protein intakes of the preschoolers. There were significant associations between mother's business ventures and anthropometric indices, energy and protein intakes as well as health status of the preschool children $(p<0.05)$. There were similar observations in health care and treatment measures of the preschool children. Women entrepreneurship skills improve the income of mothers which in turn enhances the nutrition and health status of preschool children. Government should establish more entrepreneur skill training centres at Local Government Areas as this would assist women to improve their skills.
\end{abstract}

Key words: anthropometric indices, preschool children, nutrition

\section{INTRODUCTION}

Nigerian women, similar to other women throughout Africa have always worked as farmers, food processors, traders in farm products and cooked foods, wavers, spinners, relatively few have been absorbed in modern sector employments, while others are self employed as skilled workers like seamstress, garri making, soap makers (NPC/UNICEF, 2001). African women carry important proportion of work load in food crop production, animal husbandry, food and distribution trade (Azikiwe, 1990). Out of economic necessity, women have been forced out of her traditional role of full time housewife to become part and parcel of the labour force (Rathnayake and Weerahewa, 2005). Women now constitute one quarter of industrial workers and $40 \%$ of agricultural and service workers (Madueke, 2000)

Many women assume important economic responsibilities. They are the major actors in human resources development of children during their critical preschool years. Women contribute immensely to the family income, though the father is the head of the family but women are the nation's builder. The dietary intake of a preschool child and the family as a whole depends solely on the mother's income. Rathnayaka and Weerahewa (2005) pointed out that women performance in feeding her family members depends on her income. Makombe (2005) revealed that the daily intake of nutrients added to avoid malnutrition in the childhood is related to the mother's income as well as her education. Children whose mothers have insufficient income are prone to poor physical and mental development during the early stages of life (Mekombe, 2005) and he also reported a relationship between infection and malnutrition.

Childcare has been a primary concern in almost all the communities of the world. The Nigerian child is the future of the nation and the hope of the continuity of human race. 
Therefore, his welfare and rights must always be guarantee and protected by the society. The emphasis on women acquisition of health as an essential tool for achieving a better life for themselves and their families has been established. This study focused on determining women entrepreneurial households and its effects on nutritional and health status of preschool children.

\section{METHODOLOGY}

The study was carried out in Ohaji local government area, in Imo State. The sample population of preschool children aged 2-5 years of both sexes in three nursery and primary schools were taken according to the standard procedure of WHO (1976). Z-score values for anthropometric indices; weight for age, height for age, and weight for height indices were calculated by the use of National Centre of Health Statistics (NCHS) reference population (NCHS 1976). The indices were converted to standard deviation, (z-scores) using the formula below.

\section{$\mathrm{Z}-$ Score $=\underline{\text { Child measurement }- \text { median value }}$ \\ SD value}

The energy and protein intakes were obtain using 24 hour recall method. The subjects were asked to recall all the foods eaten and drunk at inside and outside home in the previous day and the data was recorded. The food composition table (Platt 1986) was used to calculate the energy and protein intakes of the preschool children.

Pretested and structured detailed questionnaire distributed among the preschool children mother's was used to obtain information the business ventures or entrepreneur skills of the preschool children's mothers. Those whose mothers were not educated were interviewed. Similarly, children's health and care status were obtained through the questionnaire by the help of the children's parents. The percentage distribution of the preschool children in the classified various sub-levels of the variables, as well as their means values (where necessary) where obtained.

Student T-test was carried out to determine the levels of significance of differences in the means of the anthropometric indices of the preschool children between sexes and groups while Chi-square test was used to determine the association between the mother's local business ventures and anthropometric indices of preschool children.

\section{RESULTS AND DISCUSSIONS}

Table 1 shows that the mothers of the preschool children were engaged in different local entrepreneurial ventures in the locality. This observation agree with Kantor (2005) who reported that African woman is not just a woman that cooks and cleans the house, but farms, travels and engages in all forms of income generating activities. This is due to the fact that both educated and illiterate women hardly make ends meet irrespective of their multiple entrepreneurial ventures. The women are seen engaged in unskilled business ventures in order to improve financially and the health and nutrition of members of their family. Women combine all these within the traditional role of procreation and home management. The empowerment and entrepreneurial education of women especially in the rural areas can therefore be considered very necessary.

The mean anthropometric z-scores of the preschool children whose mothers engaged locally in business ventures were significantly higher than those children their mothers are not with other skills except garri making for household consumption (Table 2). The observations could be explained with the fact that women of multiple business ventures are well disposed to assist their husbands during periods of financial crisis in the households. 
Women have contributed even more than their counterparts in problem solving (Kantor, 2005)

The differences in the mean z-scores between the males and females preschool children in all the anthropometric indices for those preschool children from business venture households as well as those from non-business venture households were not significant $(\mathrm{P}>$ 0.05) (table 3). In the contemporary society most mothers are now giving equal attention to both sexes. Moreso, most parents have started realizing the importance of taking care of females like the male children in all aspects of life. Parents provide adequate care for their young ones irrespective of sex and family size. Parents who engage in multiple business ventures would be able to accommodate both sexes financially in the household.

The mean energy and protein intakes of the preschool children in both business and non-business venture households were below the recommended values of daily intakes. Although the energy and protein intakes of the preschool children from business were higher than those from non-business households, the differences were not significant. ( $P>0.05)$. Makombe (2005) revealed that the daily intake of nutrient needs to avoid malnutrition in childhood is related to the mother's income. Financial position mostly that of the mothers usually dictates the quality and quantity of purchased food irrespective of family requirements.

The frequencies and mean duration of sicknesses, among the preschool children were higher in non-business than in business ventures households (Table 5). Higher household cash incomes has been reported by Chandhury (1986) to render better access not only to food but to improve health care, good water supply, inoculations, nutrition knowledge which have been shown to be positively correlated with the nutritional status of preschool children.

Scrimshaw et al (1989) in their field study in Gutamals found that mortality rate among poorly fed children was about 400 times that in the USA and that the severity of infectious diseases rate related to the degree of nutrition deficiency. There is a relationship between infection, malnutrition and income (Scrimshaw et al 1989).

The association between business ventures of mothers' of the preschool children and the anthropometric indices of the preschool children were significant $(<0.05)$ and higher in those preschool children whose mothers were from business than non-business venture households (Table 6). This observation could be explained with the fact that the economic situation is a potent fact in determining how much and what kind of food will be available (Chandhury, 1986). Increased in maternal influence over income allocation lead to the devotion of more resources to the child, better dietary intake for the child and improved child health and nutritional intakes (Wandel and Holuboe-Ottesen, 1992). In spite of this, the capacity of women to generate income is often underutilized and even more-often unrecognized. However, women's ability to create income and control resources allocation directly affect the nutritional status of children throughout their growth.

\section{CONCLUSIONS AND RECOMMENDATIONS}

Nutritional and health status of preschool children in business venture households were better than their counterparts from non-business ventures households. Local women entrepreneurial is no doubt an obvious determinant to reducing malnutrition.

It is therefore necessary that women should engage themselves on one skill/business or the other no matter how small the profit. This could be achieved by extension of social amenities to the rural areas as it is a hindrance to their being entrepreneurial. Besides, women should endeavour to change their mindset that illiterates cannot be entrepreneurial. This recommendation if realized, would adequately increase mother's income and minimize nutritional deficiencies among preschool and the entire family. 


\section{ACKNOWLEDGEMENT}

The author wishes to thank the mothers of the preschool children for giving their consent for actualization of their study. Also, the staff and management of the Ohaji Nursery and Primary Schools for their co-operation throughout the course of the study.

\section{REFERENCES}

Azikiwe, U. (1990) A review of researchers studies on women and development. In R. O. Ohuche and M. Anyanwu (eds), Perspective in Researcher and National Development. Vol 2. Onitsha; Summer Education Publishers.

Chandhury, R. H. (1986) Determinants of nutrient adequacy in a rural area of Bangladesh. Food and Nutrition Bulletin 8 (4): $24-31$

Kantor, P. (2005) Promoting women's entrepreneurship development based on good practices women's entrepreneurship development and gender in Enterprises NEDGE. www.i.o.org (Down loaded: $2003-04-18$ )

Madueke, F. U. (2000) The role of women in Agriculture. University Press Ltd. Ibadan

Macombe, 1. (2005) Micro credit and women's empowerment: evidence from the credit scheme for productive activities of women in Tanzaria. V. Menon, Nair Gopinathan, PR and Nair, KN Noida, in Alleviating Poverty: case studies of local level linkages and processes in the developing Tanzania. Rainbow Publisher, PP 8 and 9.

National Centre for Health Statistics (NCHS) (1976). Growth charts V. S. Vital Statistics Report, Series 11:253:(1) 1-22, New York NCHS

Platt, B.S. (1975) Tables of representative values of food commonly used in tropical countries. Pergamon Press, oxford, London

Rathnayake, I. M., Weerahewa, J. (2005) Maternal employment and income affect dietary calorie adequacy in households in Sr. Lanka Food Nutri. Bull 26: 222-9

Scrimshaw, B., Pellecer, O. and Arellaro, C. (1989) Influence of recurrent infection on Nutrition and Growth of children in Chile America J. of Clin Nutrition, 26:68 PP.71

UNICEF (2001) Children's and women's rights in Nigeria: A wake up call. Situation. Assessment and Analysis 2001. Holdges A (ed) National Planning Commission: Abuja and UNICEF Nigeria, PP 352.

Wandel, M. Holmboo-Ottesen (1988). Women as nutrition mediators: a case study from Sri Lanka. Ecol. Food Nutri. 21:117-30

WHO (1976) Methodology of Nutritional Surveillance. Geneva (WHO) Technical Reports, 593. 
Table 1: Percentages of mothers with business and non business skills

\begin{tabular}{lll}
\hline Women entrepreneurial Venture /skill & $\mathrm{n}$ & $\%$ \\
Business venture household (with other skills) & 25 & 25.7 \\
Palm oil harvester & 12 & 12.3 \\
Soap making & 8 & 8.2 \\
Beverage making & 52 & 53.6 \\
Farming/Garri making & 97 & \\
Total & & \\
Non - entrepreneur venture households & & \\
Women without other skills venture (order & 100 \\
than garri making) & 100 \\
Total & \\
\hline
\end{tabular}

Note: Common business in each household is garri- making

Table 2: $\quad$ Mean anthropometric z-scare of preschool children by business and non business mothers household

\begin{tabular}{|c|c|c|c|c|c|c|}
\hline \multicolumn{7}{|c|}{ Preschool Children in business venture household } \\
\hline \multirow{4}{*}{$\begin{array}{l}\text { entrepreneurial venture } \\
\text { Anthropometric index }\end{array}$} & \multirow{4}{*}{$\mathrm{n}$} & \multirow{2}{*}{\multicolumn{2}{|c|}{$\begin{array}{l}\text { Entrepreneurial venture } \\
\text { household }\end{array}$}} & \multirow{2}{*}{\multicolumn{2}{|c|}{$\begin{array}{c}\text { Non- } \\
\text { household }\end{array}$}} & \multirow{4}{*}{ SD } \\
\hline & & & & & & \\
\hline & & $\underline{\text { mean }}$ & $\mathrm{SD}$ & $\mathrm{n}$ & mean & \\
\hline & & Z-score & & - & z-score & \\
\hline weight for age & $\overline{97}$ & 0.49 & $\overline{0.77}$ & 100 & 0.39 & 0.36 \\
\hline Height for age & 97 & 0.97 & 0.96 & 100 & 0.62 & 1.20 \\
\hline weight for height & 97 & 0.73 & 0.63 & 100 & 0.59 & 1.29 \\
\hline
\end{tabular}
1) $\quad \mathrm{P}<0.05$, t- ratio $=2.0854$
2) $\quad \mathrm{P}<0.05, \mathrm{t}-$ ratio $=2.0175$
3) $\quad \mathrm{P}<0.05 ; \mathrm{t}-$ ratio $=3.4364$ 
Journal of Agriculture and Social Research (JASR) VOL. 10, No. 1, 2010

Table 3: $\quad$ Mean anthropometric indices 2-scores of preschool children by sex and business venture households

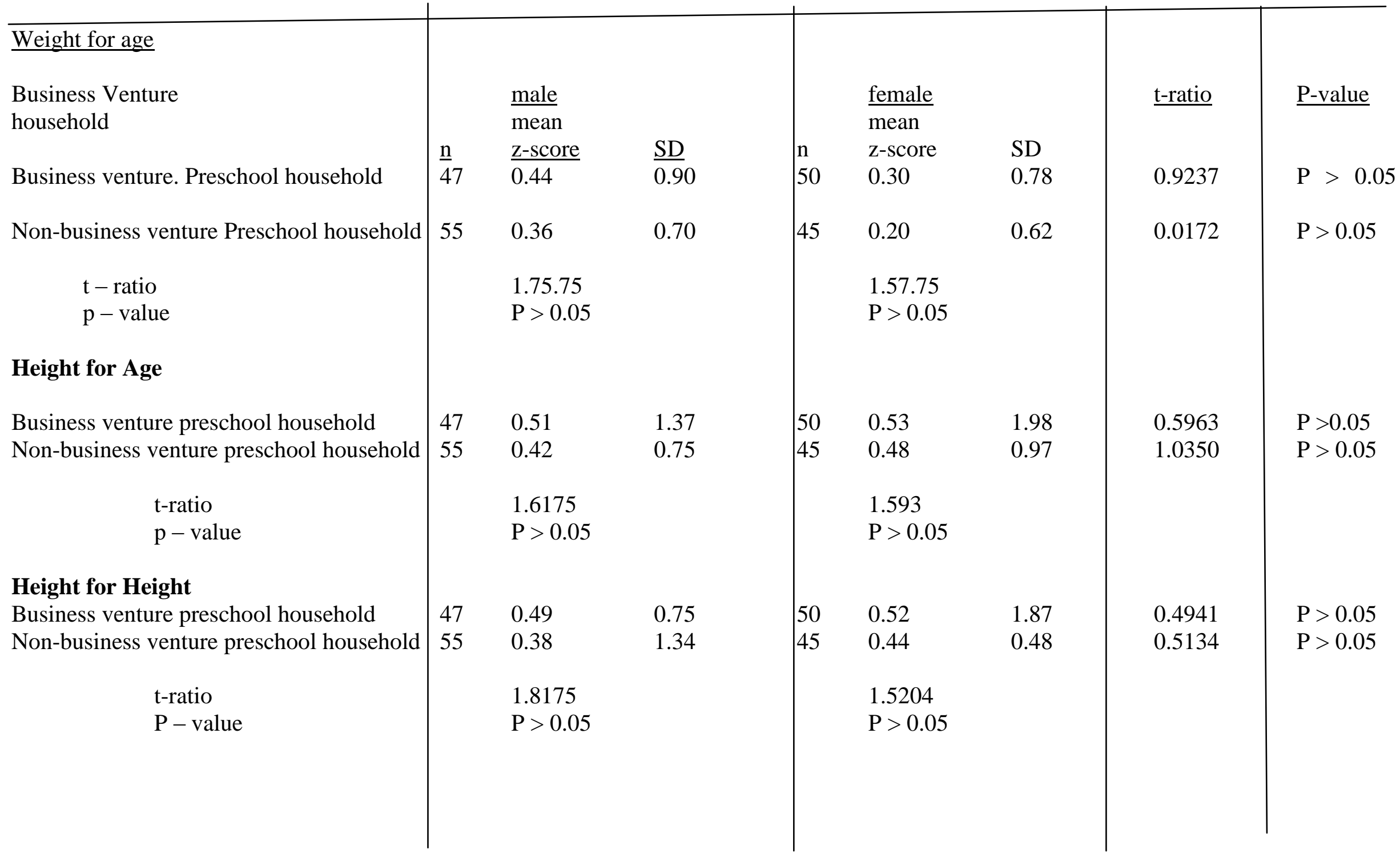


Journal of Agriculture and Social Research (JASR) VOL. 10, No. 1, 2010

Table 4: $\quad$ Mean energy and protein intakes of the preschool children by business and non business venture households

Food intakes (Kcal)

Business Ventures h/holds

Non-business

venture

$\underline{\mathrm{h} / \text { hold }}$

\begin{tabular}{|c|c|c|c|c|c|c|}
\hline \multirow{2}{*}{\multicolumn{7}{|c|}{$\frac{\text { Food Nutrient }}{\text { Energy intake (Kcal }}$}} \\
\hline & & & & & & \\
\hline male & 47 & $\begin{array}{l}1083 \\
(85)\end{array}$ & 601 & 55 & $\begin{array}{l}1013 \\
(79)\end{array}$ & 597 \\
\hline female & 50 & $\begin{array}{l}1126 \\
(89)\end{array}$ & 698 & 45 & $\begin{array}{l}1073 \\
(84)\end{array}$ & 572 \\
\hline t-ratio & & 1.3961 & & & 0.0679 & \\
\hline P-value & & $P>0.05$ & & & $P>0.05$ & \\
\hline \multicolumn{7}{|l|}{ Protein intake $(\mathrm{g})$} \\
\hline male & 47 & $\begin{array}{l}14.72 \\
(96)\end{array}$ & 2.13 & 55 & $\begin{array}{l}13.6 \\
(88)\end{array}$ & 2.69 \\
\hline female & 50 & $\begin{array}{l}14.87 \\
(97)\end{array}$ & 2.10 & 45 & $\begin{array}{l}13.91 \\
(96)\end{array}$ & 2.59 \\
\hline t-ratio & & 0.0561 & & & 0.0436 & \\
\hline P-value & & $P>0.05$ & & & $P>0.05$ & \\
\hline
\end{tabular}

NOTE: Values in parenthesis are percentage RDA met by the preschool children 
Table 5: $\quad$ Mean frequency and duration of sickness of preschool children by business and non-business venture households

Sickness types

household $\underline{\text { Business Venture household }}$

n $\quad \underline{\text { no of times }}$
Non-business venture

$\underline{\text { n }} \quad \underline{\text { no of times }}$

a) Frequency of sickness

fortnight

$\begin{array}{lllll}\text { Malaria } & 2 & 1 & 4 & 2 \\ \text { Diarrhea } & 0 & 0 & 1 & 1 \\ \text { Meashes } & 2 & 1 & 3 & 1 \\ \text { Cough } & 4 & 1 & 5 & 2 \\ \text { Others (headache) } & 5 & 1 & 6 & 2\end{array}$

b) Duration of sickness

$\begin{array}{lll}\text { sickness } & \underline{\underline{n}} & \frac{\text { mean }}{3} \\ \text { Malaria } & 6 & 0 \\ \text { Diarrhea } & 0 & 0 \\ \text { Meashes } & 3 & 3 \\ \text { Cough } & 6 & 3\end{array}$

$\underline{\mathrm{SD}}$

1.10

$\underline{n} \quad \underline{\text { mean }} \quad \underline{\mathrm{SD}}$

0.0

1.71

1.92

$15 \quad 2.22$

1.51

$\begin{array}{ll}35 & 3.74\end{array}$

1.941

Table 6: Association between the business ventures households and anthropometric indices of preschool children

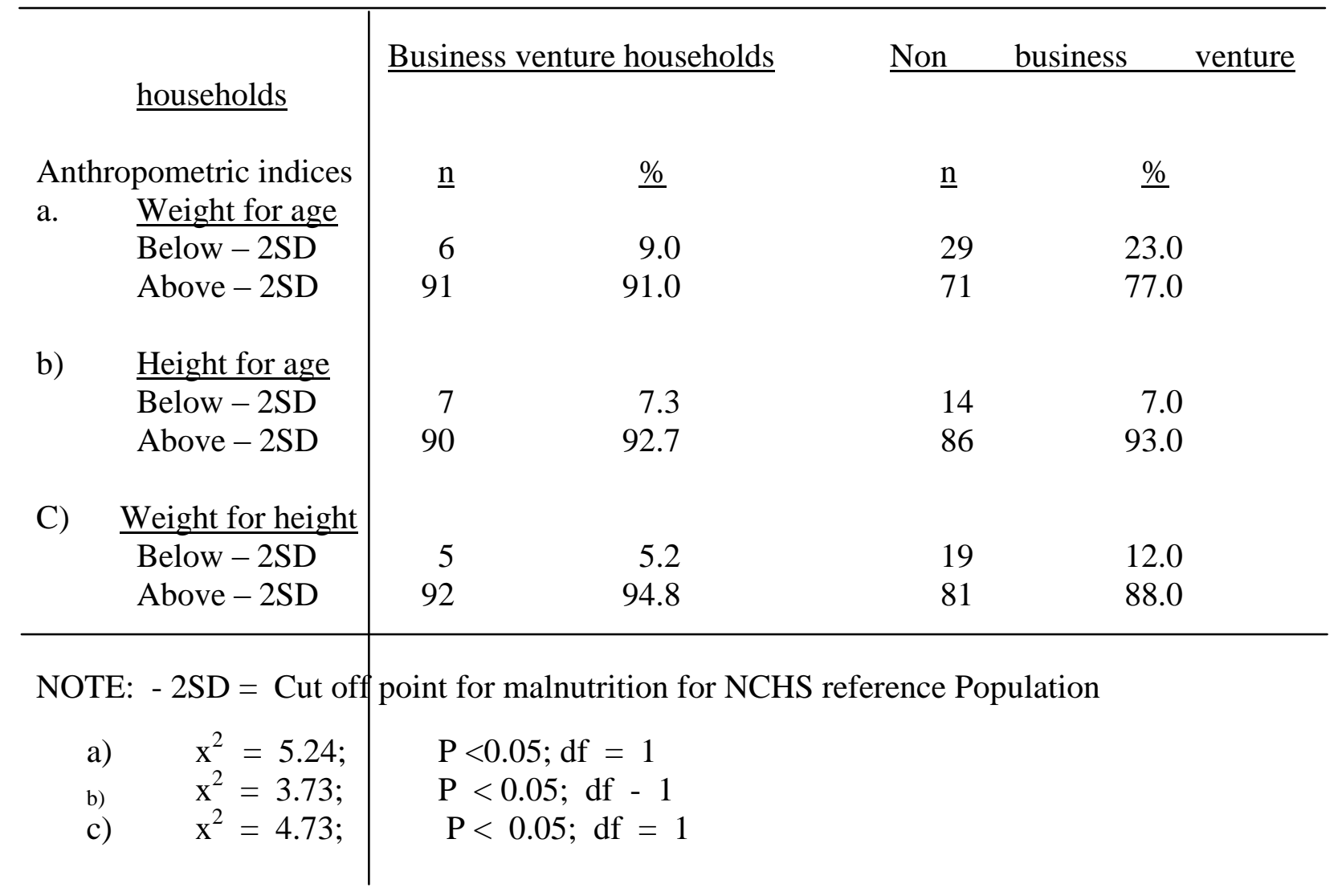

